\section{Sociologia da burocracia}

Org., introd. e trad. Edmundo Campos. 4. ed., Rio de Janeiro, Zahar. 153p.

Surge em nova edição um texto clássico de teoria das organiza cões. O livro é bastante conhecido pelos especialistas na área, pois apresenta toda a tradição de análise funcionalısta do fenômeno burocrático. Não é por acaso que alguns textos fundamentais, como os de Gouldner, Selznick, Hall e Merton, se seguem à apresentação de um estrato de Max Weber.

- Há certa confusão nessa linha de análise da obra de Weber. Confusão claramente manifesta no fato de que o "tıpo ideal" não parece perfeitamente entendido. Ora se procura estudar as "conseqüências imprevistas" do modelo burocrátıco, ora se estuda empiricamente a organização burocrática em busca de uma coincidência ou divergência com o "tipo ideal". Ocorre que o "tıpo ideal" não é testável empiricamente, ocorre que não caminhamos necessariamente para uma organização pósburocrática, só porque o "tipo ideal" apresenta claras diferenças com relação às organizações concretas. Partir das diferenças estruturais entre o modelo não parece ser um bom caminho. Melhor seria partir de onde Weber partiu, isto é: antes mesmo de ser organização, burocracia é forma de poder.

Antes, portanto, de lembrarmos algumas análises - a partir do próprio Max Weber - que se cen- traram na análise de burocracia como forma de poder, 'convém salientarmos que a leitura do livro é recomendável pelo que ele diz, isto é, pelas origens da teoria das organizações, tal como foi desenvolvida pela literatura funcionalista-sistêmica, que esclarece. É recomendável também pelo que não diz, isto é, pela sugestão de que há outras formas de analisar e perceber o fenômeno burocrático, que parece estar multo longe de um fenômeno obsoleto. Isso posto, caminhemos na elucidação de algumas linhas básicas daquela outra postura teórica. Esclarecemos, porém, que não se trata de algo semelhante a uma "escola", que não se trata de um pensamento monolítico. A postura é em princípio a mesma, isto é, uma postura de crítica à burocracia enquanto poder. A partir daí existem pontos de convergência e pontos de polêmica.

Max Weber elabora suà análise da burocracia a partir da dominação como aspecto fundamental da ação comunitária. Essa dominação manifesta-se ora em função do poder de mando e subordinação, ora mediante uma constelação de interesses. Essas manifestações com freqüência se confundem, uma transformando-se facilmente na outra. Entende-se a dominação assim referida como um estado de coisas no qual as ações dos dominados aparecem como se estes houvessem adotado como seu o conteúdo da vontade manifesta do dominante. Assim compreendida, a dominação é uma forma de poder se este pode ser definido como possibilidade que alguém ou algum grupo tem de realizar sua vontade, inclusive quando esta vai contra a dos demais agentes da ação comunitária. Toda dominação implica uma estrutura, ou seja, um chefe, seu aparato administrativo e os dominados. Isto quer dizer que estes elementos inter-relacionados compõem a estrutura de uma forma de dominação. Na medida em que toda forma de dominação está fundamentada em um conjunto de princípios no qual se baseia a exigência dé obediência, podemos falar em legitimidade. A legitimidade da dominacão burocrática está no direito racional, o que confere à burocracla sua particularidade. A burocracia racional moderna, porém, tem como ancestral a burocracia patrimonial, surgida nas formações asiáticas. A burocracia nunca se desenvolve sem uma base material adequada. A excelente análıse de Maurício Tragtenberg deixa este aspecto bem claro. $\mathrm{Na}$ burocracia patrimonial a submissão é, no entanto, de ordem pessoal. A submissão, na burocracia racional moderna, baseia-se no ideal da impessoalidade tão necessária ao cálculo e à previsibilidade inerentes ao sistema capitalista. .

Todos aqueles que de uma forma ou de outra estudam a burocracia têm que passar por Weber Aprecie-se ou não seu pensamento, ele é o principal teórico do fenômeno em questão. Há, contudo, outras formulações clássicas do fenômeno burocrático, que estão princıpalmente no jovem Marx, bem como na obra adulta de Marx e Engels. Mais uma vez seria difícil não considerar tais formulações que em alguns sentidos têm pontos em comum com Weber. Destes, o principal é a consideração da burocracia como estamento. Essas idéias foram muito desenvolvidas; e estão presentes, por exemplo, no trabalho de René Loureau. Há toda uma lıteratura que privilegia a análıse da burocracia enquanto classe.

Claude Lefort dá uma contribuição particularmente interessante a propósito da burocracia, partindo das diversas perspectivas em que o fenômeno tem sido estudado. Para ele, a burocracia pode ser vista como um grupo que tende a fazer prevalecer um certo modo de organização, desenvolvendo-se em determinadas condič̃es, e que se estende em virtude de um certo estado em que se encontra a economia e a técnica, mas que só é o que é em virtude de uma atividade social que implica um tipo de conduta específico. Muito bem, este tipo de conduta específico, que poderia ser cogitado em termos das virtudes menores do protestantısmo ascético, traduz-se para a empresa capitalista, e para o Estado, fundamentalmente em vigilância e disciplina: Ginntis e Marglin 
são dois economistas norteamericanos contemporâneos que percebem muito bem o papel da organização burocrátıca a nivel da empresa e da economia em seu conjunto

Finalmente, rião se poderia deixar de mencionar o papel que tiveram os soviéticos no desenvolvimento da crítica da burocracia. Tais contribuições estão na origem de muitas formulações modernas. Todavia, se o peso da crítıca fundamentada em Leninne e Trotski é muito grande, também não é pequeno o peso da crítica que se constrói a partir do socialismo libertárı, ou anárquico. Um dos alicerces suplementares da crítica à burocracia encontra-se ainda na discutida análise que Bruno Rizzi fez, em 1939, da burocracia soviética. Talvez, porém, o grupo mais importante da literatura contemporânea seja o representado por Cornelius Castoriadis, Claude Lefort e Paul Carden entre outros, 'em geral identificado com a publicação Socialisme ou barbarie. O primeiro tem um livro magnífico intitulado A sociedade burocrática. A advertência fundamental do autor parece ser a de que o socialismo não pode ser confundido com estatização quando o controle escapa aos trabalhadores. Luiz Carlos Bresser Pereira tenta progredir nessa linha, numa tese bastante polêmica. Paul Cardan entende a burocracia basicamente como uma estrutura social na qual a direção das atividades coletivas fica a cargo de um aparelho impessoal organizado de modo hierárquico, de acordo com critérios e métodos racionais, privilegiado economicamente e recrutado segundo regras que ele próprio adota e aplica. A esta forma de administração de pessoas e coisas chama burocratismo. Tal burocratismo nasce na produção, no Estado, nas organizações políticas e sindicais Dessas fontes espalha-se para todas as esferas da vida social, compondo a sociedade burocrática.

Estes são apenas alguns traços daquilo que o livro resenhado não diz. Que ninguém os procure nele o que vai encontrar não é menos interessante, nem é menos controvertıdo. Eu diria que deve mesmo ser bem mais controvertido, porque expressa uma tendência da teoria das organizações de legitimar a burocracia enquanto forma de poder e enquanto grupo social, bem como de legitimar a domiliação da classe burguesa que a burocracia, salvo exceções histórıcas, tende a servir. Esta legitimação não é feita pela defesa da burocracia, mas por uma crítica que ignora seus aspectos centrais e pela ilusão de que as organıações de hoje não podem mais ser consideradas burocráticas. O fato de elas não se apresentarem de acordo com o " $t i$ po ideal" não vem a favor dessa forma de análise. As organizações nunca espelharam o "tipo ideal". Resta saber quais as dimensões reais do aparato burocrático na sociedade moderna. Se a burocracia tem um caráter orgânico na sociedade moderna, e ela certamente o tem, não parece adequado subestimá-la, salvo se o fazemos numa crítica burocrática da burocracia.

Assim, com a ressalva de que o livro é maıs importante nos dıas que correm pelo que não diz do que pelo que diz, consideramo-lo absolutamente indispensável para quem quer compreender a moderna teoria das organizações. Que o leitor se prepare para muitas funcões e disfunções, funções latentes e manifestas, dimensões e propostas de estudos empíricos. É bastante oportuno, porém, chamar a atenção para um artigo clássico contido na coletânea. Trata-se do trabalho de Robert Michels sobre os partidos políticos. Ressalte-se, ainda, a bela introdução de Edmundo Campos, que levanta alguns dos problemas fundamentais que nos levam ao estudo da burocracia. Tais problemas são tantos e tão complexos que conferem a sua análise uma relevância muito especial.

Fernando Cláudio Prestes Motta
Estudos do futuro: introdu-
ção à antecipação tec-
nológica e social.

Por Henrique Rattner. Fundação Getulio Vargas.

Da multitude de facetas do problema da tecnologia, o texto concentra-se na apresentação crítica de diversas técnicas de antecipação. De fato, ante o leitor desfilam desde simples "extrapolacõos de tendências", passando por técnicas Delphos, até os "modelos giobais" tão difundidos pelo Clube de Roma. Os tópicos são apresentados de maneira clara e, no fim de cada capítulo, diversos exercícios são propostos. O texto é fluente e de leitura multo agradável. A apresentação dos tópicos, assim como as análises críticas, fica no plano das idéias gerais. Não creio ter sido intenção do autor entrar nos detalhes de cada técnica.

Quanto às extrapolações, o autor poderia ter explorado mais as arbitrariedades, tanto na escolha das formas funcionals, como na das variáveis independentes, como os critérios de ajuste pelos pontos do passado e as hıpóteses restritivas para a aplicação das técnicas conhecidas em estatística. Na técnica Delphos, os problemas dos vieses nas estimativas dos expertos, a dificuldade em estimar eventos raros, assim como outros problemas psicológicos que podem invalidar estudos de antecıpação não foram apresentados. Também não são discutidos detalhes do Dynamo de J. Forrester, utilizado nos 